\title{
7 Jewish Physicians in the Teutonic Order's Prussian State in the Late Middle Ages
}

\subsection{Introduction}

There are no records of a Jewish population residing in the State of the Teutonic Order, which existed in medieval Prussia after the thirteenth century. The only exception is Neumark (Nova Marchia), a region that was purchased from King Sigismund of Luxembourg in 1402. This was the result of the Teutonic Order's policy; due to its ongoing Crusades (e.g., the Northern Crusades) Teutonic Knights could not permit followers of other religions to live within their territory. ${ }^{1}$ One aspect of the attitude towards Jews on the part of the Order's superiors is reflected with perfect clarity in a letter of 18 May 1442 sent by the commander of Thorn (Toruń), Johann von Beenhausen, to Grand Master Konrad von Erlichshausen. The commander was reporting on talks with the Poles during the convention in Thorn and Nowa Nieszawa. ${ }^{2}$ During the meeting, the Poles demanded that Jews who were in the Kingdom of Poland at that time be permitted to run their businesses within the State of the Teutonic Order, with no greater limit being placed upon their activities than was the case for other residents of Poland, as had been formally stipulated by provisions of the 1435 Peace of Brześć Kujawski. ${ }^{3}$ The commander, however, was unwilling to agree to that without discussing it with the Grand Master and suggested that he would have an answer for the Poles within three weeks. ${ }^{4}$ It would appear that Konrad von Erlichshausen's response was negative. Nothing in known later

1 This contribution comprises a revised and updated English version of an article previously published as "Żydowscy lekarze w państwie zakonu krzyżackiego w Prusach w późnym średniowieczu" in Kwartalnik Historii Żydów (2011). - The author would like to thank the journal Kwartalnik Historii Żydów for providing permission to use this English version here.

For an overall discussion of this issue, see Nowak 1991, 136-137.

2 It was one of three court arbitration conventions that were to take place on 13 May 1442 in Strasburg (Brodnica), Thorn, and Driesen (Drezdenko). The dates of these conventions and the representatives of both parties were determined at a joint Polish and Teutonic meeting in January 1442. Up to this point, the scholarly literature has incorrectly reported that none of these court sessions took place; see also Szweda 2009, 275-276.

3 See also Weise 1970, 208. It should be noted that this refers to a document held only by the Poles and Lithuanians.

4 GStA PK, OBA 8130.

(c) BY-NC-ND (C) 2015, Duda, published by De Gruyter.

This work is licensed under the Creative Commons Attribution-NonCommercial-NoDerivatives 3.0 License. 
sources indicates that Jews from Poland were permitted to conduct business in Prussia. Thus, we can safely assume that Jews had restricted access to the Teutonic Order's territory. ${ }^{5}$ The situation did not change substantially when the Thirteen Years' War ended in $1466 .^{6}$ Nonetheless, it is important to keep in mind that while Jews were not allowed to settle in the State of the Teutonic Order, they were in contact with the locals. The information preserved in fifteenth-century Teutonic sources makes an interesting contribution to our understanding of Jewish physicians in Teutonic Prussia. This will be the focus of what follows.

\subsection{Jews as physicians}

Jews made a great contribution to the development of medieval medicine, not least by translating and transmitting Greek and Arabic medical texts into Hebrew. These translations were used by Jewish medical practitioners and enabled them to become famous for their knowledge. However, the special esteem enjoyed by Jewish doctors was a result of their activity as practitioners. A relatively large number of Jewish physicians were involved in the treatment of patients. ${ }^{7}$ Joseph Shatzmiller has pointed out that although Jews constituted just one percent of medieval society, in certain places and times Jewish physicians accounted for half or more of the medical practitioners. ${ }^{8}$ They gained knowledge and experience through frequent contact with patients. Furthermore, travelling between communities and corresponding with rabbis and other physicians were important ways in which they increased their knowledge. ${ }^{9}$

In the Middle Ages, Jewish physicians primarily practised in Jewish communities: This can be seen quite clearly in the cases of the Iberian Peninsula, Italy, and southern France. ${ }^{10}$ They needed licentia practicandi to practise their profession, and only qualified physicians received a licence. ${ }^{11}$ In 1140 , King

5 Recent research presents a different perspective on this matter. See also the introduction and Cordelia Heß's article in this volume.

6 See also Nowak 1998, 13.

7 Efron 2001, 15-16.

8 Shatzmiller 1994, 1.

9 Efron 2001, 17.

10 Siraisi 1990, 29. For more on Jewish physicians in the Middle Ages, see, among others, Roth 1953, 834-843; Shatzmiller 1994, 1-139; Jankrift 2004, 139-154.

11 Shatzmiller 1994, 14. 
Roger II of Sicily issued the first regulation requiring physicians to pass an obligatory examination. He hoped this would ensure decent medical care for those under his rule. Analogous legislation appeared in other countries over the course of the subsequent centuries: the Liber Augustalis enacted by Emperor Frederick II; regulations created by Count Charles of Anjou; provisions established in Florence and in the Kingdom of Valencia. ${ }^{12}$ Although these regulations did not generally mention Jews, the fact that there were numerous licensed Jewish physicians practising in Spain, Italy, and France indicates that they adhered to the law. ${ }^{13}$

It is assumed that physicians practising in the Middle Ages had received an education. Where did Jews study? A great number of Jews received their education within the family, with young Jewish men studying with their fathers and their fathers-in-law. This is confirmed by the Jewish physician dynasties that existed, as well as by the contents of marriage agreements. There were, however, also Jews, particularly those who aspired to be surgeons, who paid to study with private teachers. There are sources that suggest there were cases where several families employed one teacher to instruct a group of their children. In this context, it is worth noting that recent research indicates that there were some Jews connected to the medieval European universities. Jews were found on the faculty of the famed school of medicine in Montpellier and at Italian universities, including those in Pavia, Bologna, Padua, and Siena. ${ }^{14}$

Beginning in the thirteenth century, secular and ecclesiastical authorities increasingly banned Jews from treating Christian patients. The prohibition was announced at the synod of Trèves (1227). Subsequently, in 1254, the two synods of Albi ruled that Christians who turned to Jewish physicians for medical treatment would be excommunicated. These regulations were the result of a fear that Jews would block Christians' access to the last rites. Additional hostile bans were put in place in the fourteenth century during the proceedings of the councils of Valladolid (1322), Salamanca (1335), and Avignon (1337).

This was also the point at which secular legislators were at their most restrictive. In 1310, Frederick III of Sicily established punishments for both physicians and patients. On the basis of this regulation, Jews would be imprisoned for at least one year, and Christians for three months. While in prison both Jews and Christians would be restricted to a diet of bread and water; moreover, Jews would see any remuneration and salaries they had received confiscated and donated to the poor. The sense of the edict promulgated by Count Charles

12 Shatzmiller 1994, 14-15; Jankrift 2003, 45-47.

13 See also Shatzmiller 1994, 16-22.

14 See also Shatzmiller 1994, 22-35. 
II of Provence in 1306 is much the same. Nonetheless, Jewish physicians did treat Christian patients. In fact, during the Avignon Papacy, the pope availed himself of Jewish physicians. ${ }^{15}$ Dozens of Jewish physicians had remarkable careers - at the court of Aragón, for example. ${ }^{16}$ Due to a lack of properly qualified people, Jews not infrequently acted as city physicians. Very often commoners also used the medical treatments offered by Jewish physicians. Not being members of a guild, Jews provided a wide range of services. Furthermore, they gave medical assistance at competitive prices and probably filled prescriptions cheaper than Christian pharmacists. In addition, patients were convinced that the unfavourable legal situation of Jewish physicians forced them to perform their duties more carefully than their Christian counterparts. ${ }^{17}$

\subsection{Jewish physicians in the State of the Teutonic Order}

Jewish physicians were also present in the State of the Teutonic Order in fifteenth-century Prussia. Sources from former Teutonic Order Grand Masters' archives currently gathered in Geheimes Staatsarchiv Preußischer Kulturbesitz in Berlin-Dahlem allow us to point to two Jewish physicians temporarily present in the Teutonic Knights' State in Prussia. The first, named Meyen, passed through Prussia in 1446 and visited the territory again in 1448 and 1449. The second, Jacob, was in contact with the Teutonic Knights as a diplomat of Polish official Mikołaj Szarlejski. Tham von Hochberg, personal physician of Grand Master Martin Truchsess, will also be discussed below. Tham probably did not have Jewish roots, but his opponents intended to destroy his reputation by accusing him of being a Jewish convert.

\subsubsection{Meyen}

The first Jewish physician present in Prussia can be found in a historical source dating to 12 December 1446. On that date, in Bittau (Bytów), Grand Master Konrad von Erlichshausen provided safe conduct for a Poznań-based Jewish physician named Meyen. This document allowed the physician to safely enter

15 See also Siraisi 1990, 29-30; Shatzmiller 1994, 90-93.

16 See also Shatzmiller 1994, 56-77.

17 Efron 2001, 36-37. 
the State of the Teutonic Order and remain there for a specified period, after which he was free to leave unhindered - however with one stipulation: He could not work as a physician. ${ }^{18}$ The fact that the Teutonic Order's superior explicitly forbad Meyen to provide any medical advice during his stay in the State of the Teutonic Order might be the result of mistrust or of prejudice against Jews and their practices. In any case, the short period of safe conduct, dating from its issuance until 14 February of the following year - i.e., slightly more than two months - seems to corroborate the claim that this document probably only entitled the Jew to pass through the Teutonic Order's territory and made a longer stay impossible. That safe conduct was issued at the castle in Bittau, located near the border, suggests the possibility that Meyen was making his way to or from the Duchy of Pomerania - later sources support this conjecture.

In all probability, it is the same Jewish physician who appears in other sources. Despite a certain inconsistency with the name (Meyne, ${ }^{19}$ Meyen, ${ }^{20}$ Meiger, ${ }^{21}$ Meygen, ${ }^{22}$ Maher ${ }^{23}$ ) and his place of residence, it seems reasonable to presume that this is the physician named Meiger from Nowa Nieszawa in Cuiavia (Kujawy), who was first mentioned in historical sources in $1448 .{ }^{24}$ At that point, Nowa Nieszawa had only been part of the Kingdom of Poland for a brief time - since the 1422 Treaty of Melno. Previously, it had been a part of the State of the Teutonic Order. When a trade centre competing with nearby Thorn had developed in Nowa Nieszawa under the rule of the Polish king, Polish Jews had settled there. The fact that Meiger lived in Poznań in 1446, and relocated to Nowa Nieszawa in 1448 would seem to corroborate the claim that the Jews in Nowa Nieszawa had originally come from Greater Poland. ${ }^{25}$

As previously mentioned, historical references to Meyen are also found in sources dated 1448-1449. The entry book of the Grand Master's chancery indi-

18 GStA PK, OF 16, 299.

19 GStA PK, OF 16, 299.

20 GStA PK, OF 17, 179-180. It should be noted that in the document register providing the content of the 1449 safe conduct, there was an additional abbreviated form of this name, "Mey" (Hubatsch and Joachim 1948, no. 9829). It is difficult to determine why the editors used it.

21 GStA PK, OBA 9561.

22 GStA PK, OF 17, 809.

23 GStA PK, OBA 9842.

24 For additional information about this individual, see Jóźwiak 2002, 44-47; Broda 2011, 436-440; Jóźwiak and Trupinda 2011, 265-266.

25 For additional information about the relations between the Jews of Nowa Nieszawa and the Jews of Poznań, see Jóźwiak 2002, 42-44. 
cates that safe conduct was granted on 27 January 1449 by the Teutonic Order's superior in Elbing (Elbląg) and was valid until 1 June 1449. It guaranteed - on behalf of the authorities, officials, and subjects - complete legal immunity and safe round-trip passage on a specifically determined route between Thorn and Marienburg (Malbork). This document applied to the Jewish physician 'Meyen' and his travelling companion, also a Jew. ${ }^{26}$ Two weeks previously (14 January 1449), Grand Master Konrad von Erlichshausen had requested that the castellan of Kruszwica, Jan Kretkowski, who was also the starost of Cuiavia, send Meygen, a Jew and physician based in Nowa Nieszawa, to Prussia, at the fervent request of the Prussian knight Hans von Baysen, ${ }^{27}$ who wished to engage his professional medical services. The Order's superior promised to issue safe conduct for the physician and his companion, who was also a Jew, so that they could proceed safely to Marienburg. He also forbad them to stay in any other large towns within the State of the Teutonic Order. ${ }^{28}$ The letter clearly referred to an educated Jewish physician from Nowa Nieszawa. The dates of both of these documents, as well as a similar travel route and the similar names, prove that the physician in question was Meyen. There is, however, room for doubt as to his place of residence, since in 1449 Konrad von Erlichshausen requested the help of a physician from Nowa Nieszawa, while the bearer of the safe conduct issued in 1446, Meyen, was a resident of Poznań. We can safely assume, in any case, that Meyen had moved from Poznań to Nowa Nieszawa after 1446. He probably moved before 17 June 1448, since that was the date of the letter sent by the Teutonic Order's official in Bittau to the Grand Master, mentioning the "magister Meiger der Yeden, der zcu Diebaw wonnt [Master Meiger the Jew who resides in Dybowo (this is the name that was used in some sources for Nowa Nieszawa)]", located across the border from Thorn. ${ }^{29}$ Moreover, Meiger must certainly have been educated, as the letter referred to him as 'Master'. Despite the fact that his name was spelled differently, there is no doubt that the letter refers to the same person.

The 1448 letter, written by a Teutonic official from Bittau, seems to indicate that on this occasion the physician Meyen and a knight from Pomerania, Ludwik Massow, were sent to Marienburg by Jarosław, the Duchy of Słupsk's bailiff. The Teutonic official expressed the hope that they would be of service to the Grand Master, but did not specify the nature of the service in question. ${ }^{30}$

26 GStA PK, OF 17, 179-180.

27 Hans von Baysen was a knight from the Osterode (Ostróda) region who suffered from rheumatism and related ailments. See Biskup 1992, 70-72.

28 GStA PK, OF 17, 809.

29 GStA PK, OBA 9561.

30 GStA PK, OBA 9561. 
However, it seems likely that he required a medical consultation. Previous research connects the presence of Master Meyen in the Duchy of Słupsk with medical services: He subsequently travelled to the capital of the State of the Teutonic Order. Sławomir Jóźwiak assumed that the Jew from Nowa Nieszawa was treating Eric I of Pomerania, the dethroned king of Denmark, Norway, and Sweden, who was nearly 70 at the time. ${ }^{31}$ However, it is not clear that Eric I of Pomerania was living in the Duchy of Słupsk in 1448, as he had been residing in Gotland since 1438. According to Antoni Czacharowski, following the death of Bogusław IX in 1446, Eric moved to Darłowo. ${ }^{32}$ Recent literature, however, tells us that Eric I may not have left Gotland until as late as $1449 .{ }^{33}$ The presence of Meyen within the area of the Duchy of Pomerania in 1448, which is confirmed by historical sources, seems to corroborate an earlier assumption that in 1446 he was practising medicine in that territory.

The historical sources do not allow us to specify the length of Master Meyen's stay in Marienburg in 1448. In early 1449, there is mention of the physician being present in Nowa Nieszawa. Three sources from that period include information about Master Meyen. The earliest is the aforementioned 14 January 1449 letter, sent by Konrad von Erlichshausen to starost Jan Kretkowski, asking the latter to send the physician. ${ }^{34}$ Another reference to the physician can be found in the copy of the 27 January 1449 safe conduct issued for Meyen, which was preserved in the entry book kept by the Grand Master's chancery. ${ }^{35}$ The last and most extensive reference to the nature of Meyen's journey to Prussia is found in starost Jan Kretkowski's 11 February 1449 reply to Konrad von Erlichshausen. Kretkowski accepted the request of the Teutonic Order's superior and agreed to send Master Meyen to the Grand Master. ${ }^{36}$ While travelling to Marienburg - as we read in the letter - Meyen was to stop in Thorn to begin treating Hans von Baysen. Therefore, Kretkowski - as his letter to the Grand Master made explicit - informed the local commander that if the knight from Prussia came to Thorn, he would need to provide him with appropriate accommodation for Meyen to begin the patient's treatment. However, Hans von Baysen did

31 Jóźwiak 2002, 45-46.

32 Czacharowski 1981, 100.

33 Rymar 2005, 332.

34 GStA PK, OF 17, 809.

35 GStA PK, OF 17, 179-180.

36 GStA PK, OBA 9842. In this source, the name of the Jewish physician appears in another form: Maher. Nonetheless, the date the letter was issued (a month later than the letter of the Grand Master), and the information it contained make it perfectly clear that it was a reply to Konrad von Erlichshausen's request, and thus referred to the same Jewish physician. See also GStA PK, OF 17, 809. 
not come to Thorn, ${ }^{37}$ so Kretkowski sent Meyen directly to the capital of the State of the Teutonic Order. He was accompanied by the burgher and nobleman Mikołaj Scharar, a member of the starost's household. ${ }^{38}$ Although - as earlier letters of the Grand Master seem to imply - the safe conduct was issued for two Jews, neither the starost's letter nor scholarly findings regarding Mikołaj Scharar suggest that Meyen's companion was a Jew. In the further section of his letter, the starost of Cuiavia asked the Grand Master to guarantee safety and immunity for the Jewish physician on his return trip. He also wished Konrad von Erlichshausen good health and blessings. ${ }^{39}$

In previous scholarship, this information has led to the erroneous assumption that the aim of Meyen's stay in Marienburg was to treat the Order's superior. ${ }^{40}$ In fact, this supposition cannot be confirmed. It should be emphasized that in his letter the Grand Master was asking for medical consultation for Hans von Baysen. ${ }^{41}$ Although Kretkowski's wishes of good health might create the impression that Master Meyen was to treat the Order's superior in Marienburg, ${ }^{42}$ there is no evidence to corroborate this assumption. Kretkowski's good wishes might simply be a slightly unconventional conclusion to a letter. We have to consider the alternate assumption that Meyen went to Marienburg to treat Hans von Baysen, not the Grand Master. Keep in mind that it was the Prussian knight who encouraged Konrad von Erlichshausen to request that the starost of Cuiavia send the Jewish physician. Moreover, in the 14 January 1449 letter, the Grand Master made no mention of a short stay on the part of the physician in Thorn, nor he did not permit the physician to stop in any of the Teutonic Order's towns. He simply indicated that his safe conduct would secure Meyen's safe trip to Marienburg. ${ }^{43}$ Thorn was mentioned in the second letter, written nearly two weeks later (27 January 1449) as an alternate destina-

37 Jóźwiak (2002, 46) presumed that the fact that Hans von Baysen was not in Thorn was likely the result of his poor health.

38 Most probably this refers to Niclos (Mikołaj) Scharar, a burgher from Rypin, who was native of Thorn. In the sources, he has been identified with a secret informer from the Teutonic Order, who was active in the Kingdom of Poland in 1442-1453, and who was using pseudonyms, such as N. S. and N. S. Arman. The relations between Scharar and the starost of Cuiavia confirm this assumption in this source. Therefore, we know that N. S. Arman was a member of Jan Kretkowski's son Andrzej’s retinue in November 1452 and was one of King Władysław Jagiełł’s widow's attendents, Zofia Holszańska. See also Jóźwiak 2005, 47-52; Broda 2011, 439.

39 GStA PK, OBA 9842.

40 Jóźwiak 2002, 45.

41 GStA PK, OF 17, 809.

42 Jóźwiak (2002, 46) ascribed a very similar purpose to Meyen's visit at the Grand Master's court in Marienburg in 1448.

43 GStA PK, OF 17, 809. 
tion. The letter specified that Meyen and his companion were to go to Thorn, and then on to the capital of the State of the Teutonic Order. ${ }^{44}$ This information is supplemented by Kretkowski's letter informing the Grand Master that as Hans von Baysen had not come to Thorn, he would send the Jewish physician to the Grand Master's court. ${ }^{45}$ Therefore, we can assume that the ailing knight was waiting for Meyen in Marienburg or intended to go there. There are, however, no historical sources to corroborate this conjecture.

Regardless of who it was that Meyen was to treat in Marienburg, the effort undertaken to facilitate his trip to Marienburg reflects a high degree of respect for his medical skills. It appears that Meyen's reputation led to numerous wellpaid trips abroad to practise medicine. These trips might have been behind the physician's decision to relocate from Poznań to Nowa Nieszawa, which was situated across from Thorn. His move to this border town certainly facilitated his trips within the Teutonic Order's territory, and also shortened the distance to both Marienburg and the Duchy of Pomerania. He might also have been encouraged to move by other factors, such as the opportunity to live in an economically thriving, though still developing, town, which would have been attractive to a resourceful person, or a desire to join other members of the Jewish population who had left Poznań shortly before and settled in Nowa Nieszawa. ${ }^{46}$

\subsubsection{Jacob}

Another Jewish physician active in medieval Prussia was a man named Jacob. References found in historical sources leave no doubts about his profession and indicate his Jewish background. In letters, he was referred to as "Jacobus Judeus medicus [the Jew Jacob the doctor]". ${ }^{47}$ Yet, his stays in the State of the Teutonic Order were not connected with medical services, or at least there is no evidence that this was the case. This physician acted as an intermediary in secret negotiations between Mikołaj Szarlejski, the starost of Bydgoszcz, as well as the voivode of Brześć-Cuiavia, and Grand Master Ludwig von Erlichshausen. In the face of an imminent internal conflict with the Prussian Confed-

44 GStA PK, OF 17, 179-180.

45 GStA PK, OBA 9842.

46 For more on the development of Nowa Nieszawa in the first half of the fifteenth century, the settlement of the Jewish population in this town, and its origin, see Jóźwiak 2002, 40-44; Jóźwiak 2004, 42.

47 GStA PK, OBA 12688, 12708. 
eration, the Teutonic Order hoped to win favour with the Polish official who had authority over the border area. The role performed by the starost's physician is explained in two letters of authorization prepared by Szarlejski. The first was issued on 6 January 1454 in Bydgoszcz. ${ }^{48}$ With the document in hand, the physician made a short trip to the capital of the Teutonic Order's Prussian State. Following this first trip, Jacob probably went to Włocławek, where Marian Biskup assumes the starost of Bydgoszcz was staying. The latter was probably on his way to meet King Casimir IV Jagiellon. Szarlejski listened to Jacob's report and received recommendations from the Order's superior (unfortunately, we do not know what they were). Most probably, the voivode accepted them. ${ }^{49}$ On 11 January 1454, the voivode issued another letter of authorization for the physician, once again sending him to Marienburg. ${ }^{50}$ Before the end of the negotiations conducted by Jacob in the capital of the State of the Teutonic Order, it was agreed that Szarlejski would stay at the Teutonic castle in Althaus (Starogród), near Culm (Chełmno). Moreover, Ludwig von Erlichshausen used the Jewish physician to deliver the starost a letter with a draft of the agreement enclosed. In accordance with that draft, in the event of confederates in Prussia taking up arms against the Teutonic Order, the voivode would side with the Teutonic Order. Moreover, Szarlejski was to prevent the recruiting of mercenaries from the Kingdom of Poland and to impede regular troops from other areas from marching through the territory of Cuiavia. He was also obliged to send armed knights to the aid of the Teutonic Order within four weeks of a request to that effect. Furthermore, if necessary, the starost was to place the stronghold in Bydgoszcz at the Grand Master's disposal. For his part, Ludwig von Erlichshausen, if he deemed it reasonable, promised to make the castle in Althaus available to the Polish official. The Order's superior also demanded that, if need be, Szarlejski would seek to influence the king and the Polish nobility in matters related to the State of the Teutonic Order. ${ }^{51}$

On the basis of the 22 January 1454 letter from the Althaus commander to the Schwetz (Świecie) commander, we can ascertain that Jacob was in Althaus at that time, 52 possibly to continue negotiations with the Teutonic Order on Szarlejski's behalf. However, there are no surviving sources that allow us to reconstruct the course of these negotiations - perceived in the scholarly litera-

48 GStA PK, OBA 12688.

49 Biskup 1959, 216-218.

50 GStA PK, OBA 12708; Biskup 1959, 216-217.

51 GStA PK, OBA 12724; Biskup 1959, 217-218.

52 GStA PK, OBA 12740; Biskup 1959, 218. 
ture as having been held solely for the sake of appearance ${ }^{53}$ - or to determine whether or not the Jewish physician was involved in them.

To sum up, the existing sources provide information about actions undertaken by the Jewish physician as an intermediary in secret talks. While we cannot exclude the possibility that Jacob also provided medical advice while carrying out his diplomatic mission in Prussia, there are no available sources that provide evidence of him doing so.

\subsubsection{Tham von Hochberg}

When discussing Jewish physicians in the State of the Teutonic Order, it is worth mentioning Doctor Tham von Hochberg. We cannot be certain of his Jewish origin. Moreover, in previous research doubts were mistakenly raised as to whether he was a physician at all. ${ }^{54}$ However, source material confirms that Hochberg took the position of personal physician to Grand Master Martin Truchsess in 1485.55 In the same year, acting as the Grand Master's doctor, Hochberg accompanied Martin Truchsess to the convention in Thorn. ${ }^{56}$ Later, for unknown reasons, he ceased his cooperation with the Grand Master's court. Afterwards, in March 1487, Doctor Tham von Hochberg sent a long letter to Grand Master Martin Truchsess offering his services. From this letter, we can infer that Hochberg, then residing in Thorn, knew that the Order's superior did not have a doctor ${ }^{57}$ and sought to win favour, sending four or five letters. He made it clear, however, that he was not sure whether or not the Grand Master had received the earlier letters, as he only replied to the last one. Even that one had been addressed to Nuremberg and did not directly reach the recipient, who was in Thorn at that time. It is likely that the problems with communication were no accident: Hochberg - as an analysis of the letter indicates - did

53 Marian Biskup (1959, 218-219) presumed that these negotiations were meant to conceal Mikołaj Szarlejski's true intentions. This supposition seems even more credible in view of the fact that as early as on 25 March 1454 the starost of Bydgoszcz, while serving at the Prussian Confederation, issued a declaration letter (GStA PK, OBA 12894).

54 Probst 1969, 172.

55 GStA PK, OF 281, 91.

56 GStA PK, OF 18a, 152.

57 The source refers to the fact that the Grand Master might not have had a 'doctor' at this point (GStA PK, OBA 17311). The term 'doctor' here does not necessarily refer to a physician, but could simply mean an educated person with a university degree. However, according to the other source (GStA PK, OF 281, 91), there is no doubt, that here the term should be understood to mean a person with a medical education. 
not have a very good reputation with the Grand Master's court in Königsberg (Kaliningrad).

Hochberg vehemently protested the rumours that were circulating about him. He insisted that suspicions that he was born out of wedlock or was a baptized Jew, as well as other slanderous claims being made about him, were only meant to damage his reputation. As a result, he asked for an opportunity to address the accusations and slander, and thereby refute his accusers. In the event that his services were rejected, Hochberg asked to be allowed to send a servant to deliver his response. He also asked for safe conduct to Königsberg (probably to address the accusations). Hochberg also informed that he was going to remain in Gdańsk, Poland, from where he would travel to the capital of the State of the Teutonic Order. ${ }^{58}$

Christian Probst has concluded that Hochberg was not employed at the Grand Master's court, because he is never again mentioned in the available sources. The safe conduct that the physician requested from the Order's superior also warrants consideration. The difficulties posed by the handwriting of the preserved letter are significant obstacles to reading and translating this document, which creates uncertainty as to the accuracy of the interpretation of some of its sections. It seems, however, that this safe conduct was meant to enable Hochberg to travel safely to Königsberg. It is, however, unclear why he was attempting to obtain safe conduct. He claimed he was not a Jew, although rumour had it that he was a baptized Jew. It is, however, well established that a convert could freely travel in the State of the Teutonic Order without this document to guarantee his safety. Most probably, he felt unsafe because the rumours about him were common knowledge. He likely applied for the safe conduct, not because it was indispensable, but because it would guarantee him a safe journey.

\subsection{Conclusion}

The appearance of the aforementioned persons within the Teutonic Order's territory in the fifteenth century would seem to confirm that the Teutonic Knights were willing to accept the temporary presence of Jewish physicians in Prussia. Meyen's previously discussed visits to the State of the Teutonic Order in 1448 and 1449 were probably related to the provision of medical services and reflect a recognition of his professional skills, even if, in 1449, he was obliged to travel

58 GStA PK, OBA 17311. 
along a pre-determined route that did not include the larger towns. We should also keep in mind the fact that in 1446, when he was passing through the State of the Teutonic Order on his way to the Duchy of Pomerania, the Order's supreme authorities categorically denied him the right to practise medicine. The attitude towards the physician Jacob would undoubtedly have been different, because he was playing a diplomatic role as the Polish starost's representative when he visited medieval Prussia in 1454, and as a result, the Teutonic knights were obliged to show him the respect due his position. The last physician mentioned above, Tham von Hochberg, had a distinct relationship with the Order's supreme authorities. He was initially the Grand Master's physician, but seems to have lost his post and become the object of the Teutonic Order's disapproval. He claimed that there was a hostile clique in Königsberg that, among other things, accused him of being a baptized Jew, preventing him from regaining a position at the Grand Master's court.

\section{Bibliography}

\section{Primary sources}

GStA PK = Geheimes Staatsarchiv Preußischer Kulturbesitz, Berlin-Dahlem, xx. Hauptabteilung:

OBA = Ordensbriefarchiv, 8130, 9561, 9842, 12688, 12708, 12724, 12740, 12894, 17311. OF = Ordensfolianten 16, 17, 18a, 281.

Hubatsch, Walter, and Erich Joachim (Eds.). Regesta historico-diplomatica Ordinis S. Mariae Theutonicorum 1198-1525. Pars 1, Vol. 1. Göttingen: Vandenhoeck \& Ruprecht, 1948. Weise, Erich (Ed.). Die Staastverträge des Deutschen Ordens in Preußen im 15. Jahrhundert. Vol. 1. Marburg: N. G. Elwert Verlag, 1970.

\section{Literature}

Biskup, Marian. Zjednoczenie Pomorza Wschodniego z Polska w połowie XV wieku. Warszawa: Państwowe Wydawnictwo Naukowe, 1959.

Biskup, Marian. "Bażyński (Baysen) Jan.” Stownik Biograficzny Pomorza Nadwiślańskiego. Vol. 1. Ed. Stanisław Gierszewski. Gdańsk: Wydawnictwo Gdańskie, 1992. 70-72.

Broda, Michalina. "Żydowscy lekarze w państwie zakonu krzyżackiego w Prusach w późnym średniowieczu.” Kwartalnik Historii Żydów 240 (2011): 435-443.

Czacharowski, Antoni. “Miasto w okresie rozdrobnienia feudalnego 1307-1478." Historia Stupska. Ed. Stanisław Gierszewski. Poznań: Wydawnictwo Poznańskie, 1981. 74-112.

Efron, John M. Medicine and the German Jews: A History. New Haven: Yale University Press, 2001. 
Jankrift, Kay Peter. Krankheit und Heilkunde im Mittelalter. Darmstadt: Wissenschaftliche Buchgesellschaft, 2003.

Jankrift, Kay Peter. "Eigenes und Fremdes. Zur sozialen Stellung jüdischer Gelehrter und ihrer Rolle für die Vermittlung von Wissen im Mittelalter." Gesundheit - Krankheit. Kulturtransfer medizinischen Wissens von der Spätantike bis in die Frühe Neuzeit. Eds. Kay Peter Jankrift and Florian Steger. Köln: Böhlau Verlag, 2004. 139-154.

Jóźwiak, Sławomir. "Kontakty komturów toruńskich z Żydami z Nowej Nieszawy w latach czterdziestych XV wieku.” Rocznik Toruński 29 (2002): 44-47.

Jóźwiak, Sławomir. “Nowa Nieszawa naprzeciw Torunia w latach 1425-1460/1462.” Dzieje Nieszawy. Vol. 1. Ed. Roman Czaja. Toruń: Towarzystwo Naukowe w Toruniu, 2004.

Jóźwiak, Sławomir. Na tropie średniowiecznych szpiegów. Wywiad i kontrwywiad w polskolitewsko-krzyżackich stosunkach politycznych w XIV i pierwszej połowie XV wieku. Inowrocław: Zakład Poligraficzno-Wydawniczy Pozkal, 2005.

Jóźwiak, Sławomir, and Janusz Trupinda. Organizacja życia na zamku krzyżackim w Malborku w czasach wielkich mistrzów (1309-1457). Malbork: Muzeum Zamkowe w Malborku, 2011.

Nowak, Zenon Hubert. “Dzieje Żydów w Prusach Królewskich do roku 1772. Charakterystyka.” Żydzi w dawnej Rzeczpospolitej. Materiaty z konferencji 'Autonomia Żydów w Rzeczpospolitej Szlacheckiej' Międzywydziałowy Zakład Historii i Kultury Żydów w Polsce, Uniwersytet Jagielloński, 22-26 IX 1986. Eds. Andrzej Link-Lenczowski and Tomasz Polański. Wrocław: Zakład Narodowy im. Ossolińskich, 1991. 136-143.

Nowak, Zenon Hubert. "Żydzi w krajach regionu battyckiego do czasów emancypacji. Charakterystyka." Studia i szkice z dziejów Żydów w regionie Battyku. Eds. Zenon Hubert Nowak and Zbigniew Karpus. Toruń: Wydawnictwo Uniwersytetu Mikołaja Kopernika, 1998. 11-22.

Probst, Christian. Der Deutsche Orden und sein Medizinalwesen in Preussen. Hospital, Firmarie und Arzt bis 1525. Bad Godesberg: Verlag Wissenschaftliches Archiv, 1969.

Roth, Cecil. "The Qualification of Jewish Physicians in the Middle Ages." Speculum. A Journal of Mediaeval Studies 28 (1953): 834-843.

Rymar, Edward. Rodowód książąt pomorskich. Szczecin: Książnica Pomorska, 2005.

Shatzmiller, Joseph. Jews, Medicine, and Medieval Society. Berkeley: University of California Press, 1994.

Siraisi, Nancy G. Medieval and Early Renaissance Medicine: An Introduction to Knowledge and Practice. Chicago: The University of Chicago Press, 1990.

Szweda, Adam. Organizacja i technika dyplomacji polskiej w stosunkach z zakonem krzyżackim w Prusach w latach 1386-1454. Toruń: Wydawnictwo Naukowe Uniwersytetu Mikołaja Kopernika, 2009. 